\title{
GRAMMATICAL COHESION IN STUDENTS' WRITING: A CASE AT UNIVERSITAS TEKNOKRAT INDONESIA
}

\author{
Afrianto \\ afrianto@teknokrat.ac.id \\ Universitas Teknokrat Indonesia Bandar Lampung
}

\begin{abstract}
This research aims at investigating the type of cohesive devices in students' writing as a part of discourse analysis. Thus, it explores sentence correlation and meaning as a whole discourse and figures out inappropriate use of the devices.This research is conducted qualitatively to the students of English Letters of Universitas Teknokrat Indonesia Bandar Lampung and employs Halliday and Hasan's (1976) conceptual framework. Further, examining the grammatical cohesion through document, this research deeply looks at the data in form of sentences. The researcher found 122 grammatical cohesive devices from three essays. Furthermore, the researcher also found 5 inappropriate uses of cohesive devices; it includes 2 additive conjunctions, 2 adversative conjunctions, and 1 temporal conjunction. It is also noted that the lacking understanding and awareness about cohesion especially on grammatical cohesion leads the students to use inappropriate cohesive devices. It then problematizes the semantic relation among ideas in the text. Thus, this research comes up with a feedback to the lecturer that the discussion of coherence and cohesion should be more intensive.
\end{abstract}

Key words: discourse analysis, cohesion, grammatical cohesion, semantic relation

\section{INTRODUCTION}

A text has words, clauses, sentences, and textual unitswhich are chained. The chain connecting those components of text is called coherence. Dealing withcoherence, not all people can do that. For example in the writing class, students sometimes miss how to connect among ideas and even misuse the cohesive devices. Along with that condition, this research tries to deeply figures out the uses of the cohesvie devices and how they are used in text. Talking about text, Halliday \& Hasan (1976, 1-3) specify text as both spoken and written passage consisting of words, phrases, and sentences correlated each other and have principle called cohesion. The cohesion connects ideas (semantic relation) among sentences to create a coherent text. Further, IldikóBerzlánovich (2008, 2) posits that cohesion takes a role as the property of text constructing the discourse pattern. Cohesion is thus one of the text properties that contribute to the organization of discourse. Further, cohesion refers to how words and various parts of a text are associated by the use of devices like conjunction, reference, substitution, ellipsis and lexical cohesion (Halliday \& Hasan 1976). Simply, cohesion is the tool to create coherence in the text, hence it connects ideas embeded in sentences or even paragraphs so that sentence to sentence, paragraph to paragraph are coordinated by cohesion. Further, acohesive device makes sentences correlated each other, the two sentences together constitute a text that is united or coherent, for example:

(1) There are three working sheets on your desk, chek them then do something needed.

(2) Indonesian tend to use Bahasa Indonesia to comunicate. This is because of many different local languages. 
The first example employs them to refer to the three working sheets. Thus it has anaphoric function giving the relation toward two sentences. In other words, them is a cohesive device making the expressions correlated each other. In the second example, the word because connects the two sentences by means of showing their causal relation. The first sentence is a consequence that occurs because of the effect of the second sentence.

The followings are further examples.

(3) John did not need to fill the enrollment form. He could do it directly via online.

(4) His imagination about the sealed city as an alternative futuristic city is out of mind. This will not happen.

(5) They really wanted to go to Jane's party but it was too late.

$\mathrm{He}$ in the third example refers to John. This is a kind of personal reference expressed through pronoun. Further, this in the fourth example refers toHis imagination about the sealed city as an alternative futuristic city is out of mind. This type of demonstrative reference used to refer to singular participant. The last sentence shows a constrastive sense by employing the word but. Here, but construes two different situations, one influences another.

It is noted that those examples above provide the uses of cohesion devices. Two of them (because and but) bridge the semantic relation between sentences. Then, the others represent what is mentioned before with pronoun (them and he) or demonstrative reference (this). It means that cohesive devices help both writer and reader to communicate through creating a coherent text and understanding a text. On the other hand, in learning process especially in writing, it is noted that coherent and cohesion are two main things students need to holistically understand.

Discussed by many researchers, coherence and cohesion are applied in some cases that are mostly in writing. This research is not the first study analyzing and discussing cohesion in texts. There are some others, such as Kuncahya's (2015) research which is focusing on the types of cohesion and the interpretation of the occurring types of cohesion in terms of compatibility as language inputs in 16 narrative texts presented in the electronic textbook of senior high school grade $\mathrm{X}$ entitled Developing English Competence. Anonther one is Astuti (2012) who describes the cohesion related to discourse opinions of politic. Specifically, she focuses on grammatical and lexical aspects that become a cohesion device of opinion discourse of politic in Kedaulatan Rakyat daily newspaper on January 2011 and the role of these aspects is in the process towards a complete and coherent text.

$$
\text { Further, Nurhayati }
$$

investigated cohesive devices errors in 66 essays written by the seventh semester students of English Department of STAIN Salatiga. This discussion is also related to translation study as what Parazaran and Motahari (2015) did. They investigated shiftings of English grammatical cohesive devices into Persian.

In addition, Husein (2014) conducted a research focusing on grammatical cohesion under corpusbased discourse analysis, he tried to explore eighth-grade Emirati EFL learners' familiarity in generating expository text. Compared to those previous studies, this current research investigates students' awareness toward grammatical cohesion in composing essays in a writing class and goes deeply to meet inappropriate cohesive devices used.

Choosen as the subject of this research is the writing class (essay writing) of English Letters Department of Universitas Teknokrat Indonesia, a private university in Bandar Lampung.

Writing has five components as developed by Jacob et. al. (1981). They 
are content, organization, vocabulary, grammar/language use and mechanics. Further, content is related to the unity, organization is related to the cohesion, language use is related to grammar, vocabulary is related to the selection of the word, and mechanism is dealt with punctuation (taken from an interview with the lecturer).

Getting the information from the lecturer, the researchers came to a decision to do an investigation in this class.Since cohesion is a unit in writing skill, the researchers conducted an investigation in essay writing class (it is in the second semester). It is because the concepts of coherence and cohesion will be better conducted after students have written their first draft of an essay, they usually have problems with coherence and, mostly, with cohesion (Farag 2013). Furthermore, the second semester students of English literature have passed writing 1 (paragraph writing) in the first semester. It means that they have already done their first writing.

Cohesion itself consists of two divisions, they are lexical and grammatical cohesion. In this case, this research aims at one of them i.e. grammatical cohesion. Further, to have a deep analysis, there are four types of grammatical cohesion discussed, they are reference, substitution, ellipsis, and conjunction. Investigating the types of grammatical cohesion of a text, the researcher would find and know how the semantic relation of the essays were constructed and decide whether or not the text is understandable, compatible and coherent. Moreover, this research does not only investigate the type of grammatical cohesion but it also focuses on the inappropriate use of cohesive devices. This is in line with the objects chosen, they are 3 essays which have poor scores because of lacking the components of writing. The essays were scored by the lecturer who handling the class. This way is to identify the inappropriate use of cohesive devices, especially grammatical cohesion.

Objectively, this research further wants to know whether or not the students are familiar and aware of the cohesive devices in their writing. It also investigates the semantic relations. Hopefully, it later gives feedback to the lecturer dealing with the discussion of coherence and cohesion in the class, especially in term of organization and grammar/language use.

\section{Discourse ANALYSIS}

Referring to text, discourse has pragmatic and semantic dimensions (Rocci 2009, 15) which means that discourse is constructed with layers of meanings; based on what is written/spoken and based on when, how, and where it is written/spoken by who (context). Harris in Blakemore (2001, 100) agrees that the terms of discourse and a text are interchangeable by stating that discourse can be studied by analogy with sentences. Representing how people use the language in communication process, discourse goes with patterns which can reveal people's convention and manner in exchanging information. However, to know the pattern of various discourses and what makes them coherence, people should do investigation. The investigation process itself is called discourse analysis. Cutting $(2002,2)$ explains that discourse analysis stresses on the structure of the text

In addition, language use is the main point in discourse analysis (Schiffrin et. al. 2001, 1). Discourse analysis studies the highest unit of language in the text, and language is studied in its context. This is because discourse is acceptable to the extent that it exhibits coherence relations between its discourses (Blakemore, 2001, 101). In other words, it goes beyond sentence level and with semantic relation among sentences or even paragraphs. 


\section{Grammatical Cohesion}

Halliday \& Hasan $(1976,4)$ posit that cohesion refers to relations of meaning that exist within the text and define it as a text. It defines something as a text because a text is a unit of meanings, not merely a form. Moreover Halliday and Hasan $(1976,8)$ also state that cohesion is a semantic relation among elements in the text that are crucial to the interpretation of one to another. It means that the cohesion is used to create a relation in a text. This relation, which can also lie on and bridge sentences, is called semantic relation. When cohesive devices are use in the sentence, sentence will be connected each other, then, create a meaning and make a text as a whole text. Determining coherence of text is also a part of discourse analysis. In this case, cohension is a tool to create a interconnected parts of a text.

Both Halliday \& Hasan (1976) also probe that cohesion occurs where the interpretation of some elements in that discourse are dependent each other. It means that one item in the sentence refers to another or other items. When it happens, the relation of cohesion is set up, and two elements are presupposing and presupposed. Thus, these two sentences can be integrated as a complete and coherent text. For example, in the sentence Wash and core six cooking apples, put them into a fireproof dish. the word 'them' presupposes to another item which is 'six cooking apple' in the preceding sentence.On other words, Halliday and Hasan conclude that the presupposition provides cohesion between the two sentences.

Further, Halliday \& Hasan (1976) classify cohesion into grammatical and lexical cohesion. The grammatical cohesion includes reference, substitution, ellipsis, and conjunction. Meanwhile, lexical cohesion includes repetition and collocation. Both of them are established with two different elements. Grammatical cohesion is established with the use of grammatical elements of the text expressing the semantic relation within and between the sentences. It includes reference, substitution, ellipsis, and conjunction.

\section{Types and Functions of}

\section{Grammatical Cohesion in Writing}

Consisting of three types (personal, demonstrative and comparative reference), reference links two items meaning that one item refers to another item mentioned previously or afterthe first item discussed (Halliday \& Hasan 1976, 38) .Different from reference, substitution connects between items of a text anaphorically and cataphorically by replacing an item with another item in the same grammatical class. It has three types; they are nominal, verbal, and clausal substitutions.

Another part of grammatical cohesion is conjunction used to create strong cohesion by the virtue of its specific meanings. By using specific conjunction, it can relate to the preceding or following text which is semantically connected to what has gone before. Thus, conjunction can establish the semantic relation. Halliday \& Hasan $(1976,248)$ posit that there are three types of conjunction. They are additive, adversative, and temporal. They have different signal words and relate sentences indifferent ways based on their actual meanings. 
Table 1: Halliday's and Hasan's Conceptual Framework of Cohesion

\begin{tabular}{|c|c|c|c|}
\hline $\begin{array}{r}\text { Type } / \\
\text { Grammat }\end{array}$ & $\begin{array}{l}\text { btype of } \\
\text { al Cohesion }\end{array}$ & Specification & Example \\
\hline \multirow{13}{*}{ Reference } & \multirow{7}{*}{ Personal } & Speaker (only) & $I, m e$, mine, $m y$ \\
\hline & & Speaker \& other person & $\begin{array}{l}\text { we, us, ours, our, they, } \\
\text { their, them }\end{array}$ \\
\hline & & Addressee & you, yours, your \\
\hline & & Other person, male & he, him, his \\
\hline & & Other person, female & she, her, hers \\
\hline & & Object & $i t, i t s$ \\
\hline & & Generalized person & one, one's \\
\hline & Demonstrative & $\begin{array}{l}\text { Proximity near } \\
\text { Proximity far }\end{array}$ & $\begin{array}{l}\text { this, these, here, now } \\
\text { that, those, there, then }\end{array}$ \\
\hline & \multirow{5}{*}{ Comparative } & Identity & $\begin{array}{l}\text { same identical, equal } \\
\text { identically }\end{array}$ \\
\hline & & Similarity & $\begin{array}{l}\text { similar additional, } \\
\text { similarly likewise so }\end{array}$ \\
\hline & & Difference & $\begin{array}{l}\text { other different else, } \\
\text { differently otherwise }\end{array}$ \\
\hline & & Quality & better, worse \\
\hline & & Quantity & more, less \\
\hline \multirow{5}{*}{ Substitution } & \multirow{3}{*}{ Nominal } & Noun head & one, one's \\
\hline & & Nominal complement & the same \\
\hline & & Zero & \\
\hline & Verbal & For verb & $\begin{array}{l}\text { do, do so, can do, can, does, } \\
\text { did, done }\end{array}$ \\
\hline & Clausal & $\begin{array}{l}\text { Positive } \\
\text { Negative }\end{array}$ & $\begin{array}{l}\text { so } \\
\text { not }\end{array}$ \\
\hline \multirow{6}{*}{ Conjunction } & \multirow{3}{*}{ Additive } & Complex & $\begin{array}{l}\text { and, and also, and too, nor; } \\
\text { and.. .no, neither, } \\
\text { Further (more), moreover, } \\
\text { additionally, besides that, } \\
\text { in addition, another thing, } \\
\text { alternatively. }\end{array}$ \\
\hline & & Comparative & $\begin{array}{l}\text { likewise, similarly, in the } \\
\text { same way, in this way on } \\
\text { the other hand, in contrast, } \\
\text { conversely, while }\end{array}$ \\
\hline & & Appositive & $\begin{array}{l}\text { that is, this is, I mean, in } \\
\text { other words, thus for } \\
\text { instance, for example }\end{array}$ \\
\hline & \multirow{3}{*}{ Adversative } & Adversative relation & \multirow{3}{*}{$\begin{array}{l}\text { yet; though; only, however, } \\
\text { nevertheless, despite, all } \\
\text { the same } \\
\text { but, and, however, on the } \\
\text { other hand, at the same } \\
\text { time, as against that } \\
\text { instead, rather than, on the } \\
\text { contrary }\end{array}$} \\
\hline & & Contrastive Relation & \\
\hline & & Corrective Relation & \\
\hline
\end{tabular}




\begin{tabular}{|c|c|c|c|}
\hline \multirow{10}{*}{$\begin{array}{c}\text { Conjunction } \\
\text { (continued) }\end{array}$} & Temporal & $\begin{array}{l}\text { Complex } \\
\text { Conclusive }\end{array}$ & $\begin{array}{l}\text { Then, and then, next, } \\
\text { afterwards, after that, } \\
\text { subsequently, first..then, } \\
\text { first..next.. the last, first, } \\
\text { second. at the same time, } \\
\text { simultaneously earlier, } \\
\text { before that, previously } \\
\text { at once, on which; just } \\
\text { before, soon, presently, later, } \\
\text { after, next time, on another } \\
\text { occasion; this time, on this } \\
\text { occasion; the last time, on a } \\
\text { previous, occasion, next day, } \\
\text { five minutes later, five } \\
\text { minutes earlier, meanwhile, } \\
\text { all this time, by this time; up } \\
\text { till that time, until then } \\
\text { finally, at last, in the end, } \\
\text { eventually, in conclusion }\end{array}$ \\
\hline & \multirow{9}{*}{ Causal } & General simple & so, thus, hence, therefore \\
\hline & & $\begin{array}{l}\text { General emphatic } \\
\text { Specific reason }\end{array}$ & $\begin{array}{l}\text { consequently, accordingly, } \\
\text { because of this } \\
\text { for this reason, on account of } \\
\text { this } \\
\text { it follows (from this), on this } \\
\text { basis }\end{array}$ \\
\hline & & Specific result & $\begin{array}{l}\text { as a result (of this), in } \\
\text { consequences (of this) } \\
\text { arising out of this }\end{array}$ \\
\hline & & Specific purpose & $\begin{array}{l}\text { for this purpose, with this } \\
\text { mind/view, with this } \\
\text { intention to this end }\end{array}$ \\
\hline & & Reversed simple & for; because, \\
\hline & & Conditional simple & then \\
\hline & & Conditional emphatic & $\begin{array}{l}\text { in that case, that being the } \\
\text { case, in such an event, under } \\
\text { those circumstances }\end{array}$ \\
\hline & & Conditional generalized & under the circumstances \\
\hline & & $\begin{array}{l}\text { Conditional reversed } \\
\text { polarity }\end{array}$ & $\begin{array}{l}\text { otherwise, under the } \\
\text { circumstance }\end{array}$ \\
\hline Ellipsis & $\begin{array}{l}\text { Nominal } \\
\text { Verbal } \\
\text { Clausal }\end{array}$ & & \\
\hline
\end{tabular}

Further, establishing semantic relation by using grammatical elements is the characteristic of ellipsis. Although it is the same with substitution, it has different structure and pattern. In ellipsis, something is understood without saying. In other words, it is substitute by zero. Ellipsis is a matter of structural relation. It is established within the sentence. There is no structural relation between the sentences. Thus, there is no need to add additional idea of cohesion to make sentences hang together. Even, by explaining the structure within the sentence, it shows the relation between 
the sentence and it is animportant aspect of texture. That is why ellipsis is really important for grammatical cohesion and written discourse analysis. There are three types of ellipsis. They are nominal, verbal and clausal ellipsis.

\section{METHOD OF RESEARCH}

This research was conducted qualitatively because it aimed at generating words produced by students rather than number or statistic (Patton and Cochran 2002; Stake 2012). The subject of this research is students of English Letters Department of Universitas Teknokrat Indonesia, Bandar Lampung.

It was objectively designed to get deep finding of writing components in texts. In other words, it examined through documents to find grammatical cohesive devices. Dealing with finding the inapropriate devices, this research went along with low score writings. There were three essays met with the data source criteria which are the last essays required in the class, the three lowest bottom of score; and lecturer's recommendation. The last essay required in the class refers to the last assignment the students ought to accomplish. It is objectively to know the improvement of students' writing.

The title of essays chosen were Cause of Teen Sex Crime (this Text 1 was scored 60); Illegal Logging (this Text 2 was scored 50); and The Cause of Teenager's Suicide (this Text 3 was scored 30). Examining the grammatical cohesion, this research deeply looked at the data in form of sentences which were later presented with their lines where they were found. Mainly this research just investigated students' production.

\section{DESCRIPTION AND ANALYSIS}

The discussion presented into two parts; types of cohesion and semantic relation. IT was equiped with tables in order to show the findings specifically. The types of grammatical cohesionwere accumulated for each essay and presented based on the coding scheme in the conceptual framework (see Table 1).

\section{Types of Cohesion}

Table 2 shows the number of type of grammatical cohesion found in the students' essays. Specifically, each type of grammatical cohesion would be presented in the table.

Table 2: Grammatical Cohesion in Text 1

\begin{tabular}{llr}
\hline \multicolumn{1}{c}{ Type } & \multicolumn{1}{c}{ Subtype } & Freq. \\
\hline Reference & Personal & 33 \\
& Demonstrative & 1 \\
Conjunction & Additive & 6 \\
& Adversative & 4 \\
& Temporal & 4 \\
& Causal & 5 \\
\hline Total & & 53
\end{tabular}

The total number of types of grammatical cohesion in Text 1 is 53 cohesive devices. It consists of reference and conjunction. However, the researcher did not find the types of substitution and ellipsis. The most occurring type of grammatical cohesion is personal reference, it occurs 33 times in Text 1. Regarding that finding, it seems that the student shows and describes the agentive subject (actor) in form the plural third person, i.e. they refering to teenagers. Demonstrative reference appears once and is used to give examples of the previous explanation. While in category of conjunction the most occurring type is additive conjunctionwhich appears 6 times, it happens because the student describes and elaborates a topic by often giving more additional information. Further, adversative conjunction appears 4 times. It is noted that those four adversative conjunctions mark a contrastive idea.

The next finding is temporal conjunction which appears 4 times, such a conjunction marks the order of ideas and always appears at the opening of each paragraph. The last conjunction found is causal conjunction which 
appears 5 times. By means of this conjunction, the student wanted to show the causal relation meaning that lacking or missing something affects something else.

Table 3: Grammatical Cohesion in Text 2

\begin{tabular}{llr}
\hline \multicolumn{1}{c}{ Type } & \multicolumn{1}{c}{ Subtype } & Freq. \\
\hline Reference & Personal & 7 \\
& Demonstrative & 6 \\
Conjunction & Additive & 5 \\
& Temporal & 6 \\
& Causal & 3 \\
Substitution & Verbal & 1 \\
Ellipsis & Nominal & 1 \\
\hline Total & & 29
\end{tabular}

There are 29 grammatical cohesive items appear in Text 2, it includes personal reference, demonstrative reference, additive conjunction, temporal conjunction, causal conjunction, verbal substitution, and nominal ellipsis.

The most occurring type of grammatical cohesion is personal reference which appears 7 times. In this essay, the student wanted to show some agentive actors who got involved in the illegal logging, it is not only the doer of this case, but it also includes other people and certain governmental office. Therefore, personal reference appears more than other grammatical cohesive devices.

Both demonstrative reference and temporal conjunction appear 6 times. Demonstrative reference used by the student is to construe that the illegal logging is such a closed problem for the society. The demonstrative reference used are this and these. Further, temporal conjunction used here is not mainly talking about time but it refers to the order of points discussed.

It is also found that the additive conjunctions which appears 5 times. This conjunction marks any additional information added by the student to complete the ideas.
Another type of conjunction is noted as well, it is causal conjunction which appears 3 times. Mainly, the student used causal conjunction to give cause and effect idea. Further, verbal substitution and nominal ellipsis appear only once.

Table 4: Grammatical Cohesion in Text 3

\begin{tabular}{llr}
\hline \multicolumn{1}{c}{ Type } & Subtype & Freq. \\
\hline Reference & Personal & 24 \\
& Demonstrative & 5 \\
Conjunction & Additive & 5 \\
& Adversative & 2 \\
& Temporal & 3 \\
Substitution & Causal & 2 \\
& Verbal & 1 \\
\hline Total & & 42
\end{tabular}

In the Text 3 entitled The Cause of Teenagers' Suicide, the researcher found 42 grammatical cohesion, they are personal reference, demonstrative reference, additive conjunction, adversative conjunction, temporal conjunction, causal conjunction, and verbal substitution.

The most occurring type of grammatical cohesion is personal reference which appears 24 times. Demonstrative reference appears 5 times while additive conjunction appears 5 times. Further, it is noted that adversative conjunction appears 2 times, temporal conjunction appears 3 times, causal conjunction appears 2 times, and verbal substitution only appears once.

Then, in Text 3 , the researchers did not found any ellipsis. Each of the findings in this text shows the same things as the previous findings, for instance personal reference, it refers to the agentive actor described in form of subject and object. It can be reported that temporal conjunctions used refer two different things, the first one is now which refers to time while another one is in conclusion which marks an end of discussion. 
Demonstrative reference used by the student is to show that the problem discussed is a closed problem to the reader, on other words it also reflects student's affective side.

In order to complete the main idea, the student gave more additional ideas by using additive conjunction. Along with using additive conjunction, the student employed causal conjunction to give cause and effect circumstance to the essay. Another finding is adversative conjunction which is basically used by the student to construe the contrastive situation.

\section{Inappropriate Grammatical Cohesive Devices}

It could be reported that there are several inappropriate uses of grammatical cohesion written by the students. The inappropriate uses happened to additive conjunction, temporal conjunction, and adversative conjunction. The mistakes and inappropriate uses are as follow:

\section{beside}

Beside, teenagers don't have the basic of religion. Maybe in their family, they do not get the basic knowledge of religion in their family so they don't understand of what they do (Text 1, lines 10-11).

The word beside in the text is categorized as complex additive conjunction and need too be added with 's' because it shows abstract position not concrete position. Further, the word besides functions to give additional information or additional statement (Halliday \& Hasan 1976, 249) and it falls into additive conjunction. However, in the sentence (line 10-11) the student states teenagers don't have the basic of religion (1st sentence) and second sentence is Maybe in their family, they do not get the basic knowledge of religion in their family... then the researchers thought that those two sentences have the same meaning, it means that the student did not give additional information.
Thus, the researcheR suggests that the appropriate conjunction is because. It seems that basically both sentences construe cause and effect idea, so the sentences become teenager don't have a basic of religion, because in their family, they do not get the basic knowledge of religion. Contextually, the second sentence gives a reason why teenagers do not have a basic knowledge, so an appropriate conjunction is simple reversed causal conjunction.

but

When they join with the environment, at least there are some ideas or some knowledge that they have, maybe about sexual, religion, or life. But, teenager must be careful; they could just hang out with wrong people." (Text 1, lines 17-18).

In the text above, it appears contrastive adversative conjunction but. In the researchers' opinion on the use but is inappropriate because according to Halliday and Hasan $(1976,255)$, the word but is used to connect the sentence giving a contrasting signal. Then if it is seen from the context of sentence above When they join with the environment, at least there are some ideas or some knowledge that they have, maybe about sexual, religion, or life. (preceding sentence) and the sentence teenager must be careful (following sentence), it is not contrasting but it shows the additional information so the word but is inappropriate conjunction, then the researchers suggest that the appropriate conjunction is the word and also or and since Halliday \& Hasan (1976, 242) categorize and also as well as and as additive conjunction and the use of and is to give additional information or statement. So the sentence can be When they join with the environment, at least there are some ideas or some knowledge that they have, maybe about sexual, religion, or life, and also teenager must be careful; they could just hang out with wrong people. 


\section{on the other hand}

Many people can teach them about the bad thing, because people who teach them the bad thing maybe have the same problem. On the other hand, they can get the bad influence from environment if they cannot distinguish which is good and bad (Text 1, lines 1820).

From the sentence above the researchers found a contrastive adversative conjunction which is the phrase on the other hand. This is used to give a contrasting signal. Halliday \& Hasan $(1976,255)$ say in their book that the phrase on the other hand is categorized as additive conjunction which functions to give the contrasting signal. But, it is the same as the previous case of word but in the sentence (line17-18), on the other hand phrase is not appropriate conjunction here, since in that sentence the meaning is not contrasting but adding information. So, the appropriate one is the word moreover as Halliday \& Hasan $(1976,242)$ state that the word moreover is used to add the additional information and is categorized as complex additive conjunction.

and

.....protects the earth from the sun. And from the impact makes world will be more hot because so many carbon dioxide on the air. Many effects we feel from illegal logging, this activity just... (Text 2, lines 19-21).

The reseacher found a mistake of the use of conjunction and in the text above. The student used and at the beginning of a sentence. Referring back to Halliday \& Hasan $(1976,235)$, the use of conjunction and is to connect two sentences which can give the additional information, while it is placed in between two sentences. Therefore, the reseacher determines the student used inappropriate conjunction. In addition, it can be seen from the context that the student tended to give the information of the impact of illegal logging activity which can deplete the ozone layer and make the world hotter. Thus, the reseacher suggests conjunction therefore as the substitution of and, because as a simple general causal conjunction, the word therefore is functioned to give the logical result of an activity (Halliday \& Hasan 1976, 236).

\section{finally}

....The forest no longer able to absorb the rainwater that fell in large bulk and finally a flood attack settlements." (Text 2, lines26-27).

The cohesive device found in line 26 27 is inappropriate; it seems that contextually the student wanted to give a conclusive statement. In this case, to give a conclusive statement, it is inapropriate to use and. Halliday and Hasan $(1976,149)$ posit that the word and is categorized as simple additive conjunction which functions to give additional information/statement. The researcher suggests reconstructing the sentence into The forest no longer able to absorb the rainwater that fell in large bulk. Finally a flood attack settlements. It does not need to use and. The word finally is conclusive temporal conjunction which gives cohesion toward text to signal conclusive information.

\section{Semantic Relation}

This discussion presents the analysis of semantic relation seen from grammatical cohesion. This session goes along with Text 3 entitled Illegal Logging. Each part of the analysis is presented by showing the excerpt of the text, in form of lines. There are some grammatical cohesive devices used in the text, such as this, and, therefore, they, do so, it, first, their, and then, these, the second, the last, finally, moreover, and those. In the excerpt the researchers made each grammatical cohesive devices found italicized, underlined and bold. 


\section{Excerpt 1}

Illegal logging is the harvest, purchase or sale of logs into black market. The harvesting procedure is illegal, including using means to gain access to the forest. This activity brings many losses for the forest and impact the forest sustainability (lines 1-3).

From the sentences above, the student used proximity near demonstrative reference this to refer to the word activity for illegal logging activity which stated before. Illegal logging activity can be means as an illegal tree chopping or trading (purchase and sale) the wood into black market. The student used the word this since it refers to a singular activity which is illegal logging activity. Moreover, the student also stated the word and to add the existing information. Since illegal logging activity does notonly bring losses but also impact the forest sustainability. The word and is categorized as a simple additive conjunction.

\section{Excerpt 2}

Illegal logging can cause deforestation and damage natural ecosystems such as flora and fauna. Therefore, the government must make a punishment for those who committed acts as an illegal logger. If they do so, it will reduce illegal logging activities (lines 3-6).

In the first sentence, the student also used simple additive conjunction and to give more information towards the causes of illegal logging as its not only can cause to deforestation but also can damage natural ecosystems such as flora and fauna. Moreover, the word therefore above is a type of simple causal conjunction used by the student to give the logical result of something that has been mentioned before (illegal logging issue). In this case, the government should make a law to reduce illegal logging activity. In the text (line 3-6), personal reference they refers to the governmentanaphorically. While in preceding text the government can be interpreted as they because they have the same function as a subject.

Further, verbal substitution $d o$ so'substitutes a punishment for those who committed acts as an illegal logger. The word it in the text (line 3-6) is categorized as object personal reference, where the word it refer to a punishment in preceding sentence, the word it refer to the back to give a relation in the text above, so to know what the word it being refer to, reader should go backward to get the information what it means.

\section{Excerpt 3}

Today, illegal logging makes many impacts. First, illegal logging will lose the forest sustainability as a habitation of rare flora and fauna. This impact makes many rare animals like orangutans loss their habitation. Illegal logging continuously will make forest be barren and food sources such as leafy greens and fruits for animals in the forest are lost as the impact by illegal logger. And then, when they cut down a large tree, rare plant such as orchids and medicinal plants in the surrounding is dead. These impacts make many type of rare flora and fauna will be loss and the type will be less for people to find in the world (lines 7-13).

The word first above is categorized as of simple temporal conjunction which is used to give a sequence of many impacts caused by illegal logging. This type of conjunction will be used again in the following text to give more sequential information by using another simple temporal conjunction such as then, next, and after that.

Meanwhile, the word this is a demonstrative reference which contextually refers to illegal logging In this case, illegal logging activity has an impact. To check whether or not this represents the impact of illegal logging activity, the reader should go backward to find what the preceding text which is occurred previously. It is because they are adjoining sentences and appear in the same context. This way is categorized as an anaphoric way. 
Anaphoric way is also used by the student to refer the phrase their as the referential meaning of rare animal habitation. Again, in order to check its inference, the readers can look at the preceding text.

To connect the ideas between sentences in the text (line 7-13) above, the student used the word and then. Referring to Halliday \& Hasan (1976, 261 ), the phrase and then is type of simple temporal conjunction is used to give the next idea in a form of action or event.

Meanwhile, the word they as the doer of the action in the following text refers to illegal logger occurred in the preceding text. This way of referring is determined as anaphoric way and included as the type of personal reference (other person).

In the same way, anaphoric way is also used in the next sentence by using the word these to refer to several impacts caused by illegal logging activity stated in the preceding text. In addition, Halliday \& Hasan $(1976,58)$ state that, the word these can be used to refer to something (e.g. person, thing, or event) that is close to the audience or can be used to something that has already mentioned previously.

By seeing the context in the preceding text, clauses such as: Illegal logging loose the forest sustainability as a habitation of rare flora and fauna;rare animals like orang utans loss their habitation; and food sources such as leafy greens and fruits for animals in the forest are lost can be represented the phrase these impacts.

\section{Excerpt 4}

The second illegal logging impact is forest loss as a lungs of the world. In the air there is much carbon dioxide from many activities of humans like from fumes transport (lines 14-15).

To continue to the next sequential idea, the student above used simple temporal conjunction the second to give the next information of several impacts of illegal logging activity that has been previously mentioned before.

\section{Excerpt 5}

Illegal logging activities make trees will be less and makes the function of the green leaf as a filters for carbon dioxide in the air is reduced so that the carbon dioxide in the air rise and create effect that are serious enough that the depletion of the ozone layer which protects the earth from the sun. And from the impact makes world will be more hot because so many carbon dioxide on the air. Many effects cause from illegal logging, this activity just makes forest as producer of oxygen more being low (lines 15-21).

The word so above appears between two coordinative sentences. Halliday \& Hasan $(1976,248)$ state that, by using specific conjunction, two or more sentences can relate each other and can establish the semantic relation. Therefore, the student used it to link those two sentences and to give a logical result of the impact of illegal logging activities. This type of conjunction is categorized as simple general causal used to give logical reason of cause and effect of an activity.

Besides, the writer found a mistake of the use of conjunction and in the text (lines 15-21) above. The student used and in the beginning of a sentence. Refer back to Halliday \& Hasan (1976, 235 ), the use of conjunction and is to connect two sentences which can give the additional information in the text, while it places between two sentences. Therefore, the writer determines the student above used inappropriate conjunction.

In addition, it can be seen from the context that the student above is intended to give the information of the impact of illegal logging activity which can deplete the ozone layer that can cause the world to be hotter. However, the writer suggests conjunction therefore as the substitution of and, because as a simple general causal conjunction, the word therefore is 
functioned to give the logical result of an activity (Halliday \& Hasan 1976, 236).

From the text (lines 15-21) above, the student used demonstrative reference to refer the word this activity for illegal logging activity which stated before. The student uses the word this since it refers to a singular activity which is illegal logging activity.

\section{Excerpt 6}

The last, illegal logging impact can even make death to human, one of the causing is flood. Flooding in Indonesia has claimed the treasure and soul is very large. The most visible environmental damage to the region of Sumatra newly flooded and severely eroded soil. Many people have lost their property, homes and relatives (lines 2225).

From the text above, the item the last is expressed to give sequential relation toward text above where the writer explains about impacts of illegal logging in the preceding text. Then, writer uses sequential temporal conjunction to give the last information of the impact of illegal logging.

The other cohesive device used in the text (lines 22-25) is personal reference their. The word their in the text above is possessive pronoun. The word their refers to 'people' where this item uses anaphoric way to give relation in the text.

\section{Excerpt 7}

Floods and landslides have occurred as a result of illegal logging in the remaining Indonesia. The forest no longer able to absorb the rainwater that fell in large bulk and finally a flood attack settlements (lines 25-27).

The cohesive device that occurs in the sentence lines 26-27 is inappropriate, if it is seen from the context of the sentence, the writer wants to give a conclusive statement, if the writer wants to give a conclusive statement it does not need to use and because according to Halliday and Hasan $(1976,149)$ the word and is categorized as simple additive conjunction where the function is to give additional information/statement.

The sentence in lines 26-27 should be The forest no longer able to absorb the rainwater that fell in large bulk finally a flood attack settlements. The word finally is conclusive temporal conjunction, where the word 'finally' gives cohesion toward text to signal conclusive information.

\section{Excerpt 8}

Illegal loggers live in a fancy place, while people living in the area near the forest live in poverty and_become the victims of the acts of illegal loggers. This ${ }^{1}[R B I]$ is a very painful social injustices of society. And then floods makes trees as a buffer of the soil became loose even became a landslide. $T_{h i s^{2}}$ makes trees in the forest as water absorbent to provide the source of water for the benefit of local communities, now engulfed by illegal logger. Sincethere are many impact that caused by illegal logging, government should explicitly give a sanction for establishment of forest protection, soil remediationand the establishment of forest conservation (lines 28-34).

In the sentence above the word while is comparative additive conjunction, the writer use the word while to compare the condition of illegal logger with people who live near forest. Where the condition of illegal logger and people who live near forest is different, in the first statement the writer stated illegal logger live in a fancy place and the following statement stated that people who are living in near forest live in poverty.

The writer also used simple additive conjunction and in the text (lines 3835 ), the writer used the word 'and' to connect the additional information from the preceding sentence, while in preceding sentence the writer stated Illegal loggers live in a fancy place, while people living in the area near the forest live in poverty and to connect additional information become the victims of the acts of illegal loggers the 
writer used the word 'and' to give semantic relation to the sentences.

In the text (lines 28-34) above, also the writer uses simple additive conjunction and then to give more explanation or more statement, where the student uses the word and then to connect the sentence with the preceding sentence that is stated previously, the student tries to connect the sentence This is a very painful social injustices of society with the sentence floods makes trees as a buffer of the soil became loose and eventually became a landslide' by using the word 'and then' since those two sentences are the same in the form of context which those two sentences are the impact of illegal logging.

From the text (lines 28-34) above, the writer uses demonstrative reference proximity near this. The word thisrefer to Illegal loggers live in a fancy place, while people living in the area near the forest live in poverty and become the victims of the acts of illegal loggers in preceding text.

This is anaphoric way where the word this refer back to the information which stated before, to know what the word this is, reader should go backward to get the information stated before. Then we can interpret the word this is refers to Illegal loggers live in a fancy place, while people living in the area near the forest live in poverty and become the victims of the acts of illegal loggers.

The word this refers to the event that stated in preceding text which is floods makes trees as a buffer of the soil became loose and eventually became a landslide. This anaphoric way of word this gives a cohesion to the text where reader should go backward to get the information what the word means.

\section{Excerpt 9}

Therefore, the government should make forest management and forest monitoring program to avoid the act of illegal logging. moreover, to make this program running well central government and provincial government should be cooperated with society, and other relevant agencies. Both (0) should be well-cooperated to make this program running well (lines 34-38).

In this sentence the student uses general simple causal conjunction therefore to give the logical result of something that has been mentioned before which is Since there are many impact that caused by illegal logging, government should explicitly give a sanction for establishment of forest protection, soil remediation and the establishment of forest conservation.

From that statement the student tries to give the logical result which is the government should make forest management and forest monitoring program to avoid the act of illegal logging. Then government can give a sanction for the illegal loggers.

The word moreover that is categorized as a complex addictive conjunction isused by the student to give additional information from preceding text (lines 34-38). The information added by the student is to make this program running well central government and provincial government should be cooperated with society, and other relevant agencies. That sentence is used by the student in order to add the information and the word moreover gives connection between two sentences above, so that the meanings are related each other. Thus, the text can be interpreted as follow: forest management and forest monitoring program will run well as long as the central and provincial government work together.

In the text (lines 34-38) above the researcher found nominal ellipsis in line 37. In this sentence, the ellipsis is marked by (0). The (0) is omitting the position of government \& society. Then, in the text (lines 34-38), the student also uses proximity near demonstrative reference this then the word this ${ }^{1}$ and this $^{2}$ refer to should make forest management and forest monitoring 
program, where the word this refers backward to give relation in the text above, called anaphoric way. To know what the word this refers to, the reader should go backward.

\section{Excerpt 10}

Those all about the opinion of illegal logging, illegal logging is not good activities because it will have a major impact for people's life. The government should give a hard penalty to make illegal logging do not happen again. Not only the government must also keep the forest with make an organization that can protect the forest in order to remain protected from against illegal logging (lines 39-43).

In the text (lines 39-43) the student uses proximity far personal reference those. The word those refers to the student opinion in the preceding text. This anaphoric way of those give a relation in the text by referring to backward. So, the reader can interpret what those is if he/she has already read preceding text.

Also the student uses the word it in the sentence above. Here, the word it refers to illegal logging activities. This word is personal reference in the category of object where this cohesive device refers back to the preceding sentence to give a relation toward the sentence itself (anaphoric way).

\section{Conclusion}

The description and analysis show that the students are not really familiar with the types of cohesive devices so that the devices used are not various. Moreover, the researchers found 5 inappropriate use of cohesive devices, it happened toadditive,adversative, and temporal conjunction. It is noted that in the Text 1 entitled Cause of Teen Sex Crime, there are 53 cohesive devices, in which personal reference becomesthe most cohesive devices appearing among all the type of cohesive devices, it appears 33 times. Meanwhile, in category of conjunction, the most frequent number of occurrence is additive conjunction, it appears 6 times.
Further in Text 2 with the title Illegal Logging, the researcher found 29 cohesive devices, the most occurring number of cohesive devices is personal reference which occured 7 times in the text, and in category conjunction the most occurrence cohesive used is temporal occuring 6 times. Then it was also found 1 verbal substitution and 1 nominal ellipsis.

Different from Text 1 and 2, there are 42 grammatical cohesive devices found in Text 3 entitled The Cause of Teenager's Suicide. It was noted that personal reference is the most frequent number of occurrence. It appears 24 times in the text. Meanwhile the most frequent number of occurrence in category of conjunction is additive conjunction appearing 5 times. In the category of substitution, there is only one cohesive device found, that is verbal substitution. From the number of occurring type of cohesion that appears in those 3 essays and the most frequent cohesive device used by those three students is reference.

It can finally be concluded that the students are lack of understanding about cohesion especially about grammatical cohesion. It can be seen from the inappropriate uses of cohesive devices and also the inappropriate uses of conjunction, while it is very influential in the text.

If they use cohesive devices inapropriately, the meaning of the text will not be achieved, then the semantic relation is not connected each other. The text finally will not be coherent. Readers will be hard to understand the context of the text. So awareness is needed here because the use of cohesive devices is really important to create the semantic relation and connect the sentence in the text.

Along with those circumstances, this research argues that the lecturer in this case needs to conduct more intensive discussion of coherence and cohesion in the class, especially in writing class. 


\section{REFERENCES}

Astuti, KS. 2012. Kohesi Wacana Politik Pada Rubrik Opini Surat Kabar Harian Kedaulatan Rakyat. (Undergraduate Thesis). Yogyakarta: Universitas Negeri Yogyakarta

Berzlánovich, I. 2008. Lexical Cohesion and the Organization of Discourse.Center for Language and Cognition. Groningen: University of Groningen

Blakemore, D. 2001. The Handbook of Discourse Analysis. Malden: Blackwell Publishers Inc.

Cutting, J. 2002. Pragmatics and Discourse: A Resource Book for Students. Oxon: Routledge

Farag, L. 2016. Coherence and Cohesion in Academic Writing. http://www.tesol.org/ connect/teso-resource-center/searchdetail/lesson-plans/2013/08/23/ coherence-and-cohesion-in-academicwriting.2013. Acessed on June 2016

Halliday, MAK \& Ruqaiya Hasan. 1976. Cohesion in English. London: Longman

Husein, Husein Maghawry. 2014. A Corpusbased Discourse Analysis of Grammatical Cohesive Used in Epository Essays Written by Emirati EFL Learners at Al ghazali School, Abu Dhabi. (PhD Dissertation). Dubai: The British University

Jacobs, HL, SA Zinkgraf, DR Wormuth, , VF Hartfiel, \& JB Hughey. 1981. Testing ESL Composition: a practical approach. Rowley: Newbury House

Klimova, Blanka F \& Hubackova, Sarka. 2014. "Grammatical Cohesion in
Abstracts". Procedia-Social and Behavioral Sciences, 116: 664-668

Kuncahya, Astri Ollivia. 2015. Cohesion in Narrative Texts Presented in the Electronic Textbook of Senior High School Grade X Entitled Developing English Competence.(Undergraduate Thesis. Yogyakarta: Universitas Negeri Yogyakarta

Nunan, David. 1993. Introducing Discourse Analysis. London: Penguin English

Nurhayati, Yanti. 2012. The Error Analysis on the Use of Cohesive Devices in English Writing Essay among the Seventh Semester Students of English Department of STAIN Salatiga in the Academic Year of 2011/2012. (Undergraduate Thesis). Salatiga: STAIN Salatiga

Parazaran, Saeed \& Seyyed M. Motahari,. 2015. "Investigating Grammatical Cohesive Devices: Shift of Coherence in Translating Narrative Text Type". International Journal of Foreign Language Teaching and Research, 3 (10)

Patton, MQ \& Michael Cochran. 2002. A Guide to Using Qualitative Research Methodology. Medecins Sans Frontieres

Rocci, A. 2009. Discourse: An Overview of Research in Discourse Studies. Amsterdam: John Benjamins Publishing Co.

Schiffrin, et. al. 2001. The Handbook of Discourse Analysis. Malden: Blackwell Publishers Inc.

Stake, Robert E. 2010. Qualitative Research-Studying How Things Work. New York: The Guilford Press 